\title{
A five-year perspective on the situation of haemorrhagic fever with renal syndrome and status of the hantavirus reservoirs in Europe, 2005-2010
}

P Heyman (paul.heyman@mil.be) ${ }^{1}$, C S Ceianu ${ }^{2}$, I Christova ${ }^{3}$, N Tordo ${ }^{4}$, M Beersma $^{5}$, M João Alves ${ }^{6}$, A Lundkvist ${ }^{7}$, M Hukic $^{8}$, A Papa ${ }^{9}$ A Tenorio ${ }^{10}$, H Zelena ${ }^{11}$, S Eßbauer ${ }^{12}$, I Visontai ${ }^{13}$, I Golovljova ${ }^{14}$, J Connell ${ }^{15}$, L Nicoletti ${ }^{16}$, M Van Esbroeck ${ }^{17}$, S Gjeruldsen Dudman ${ }^{18}$,

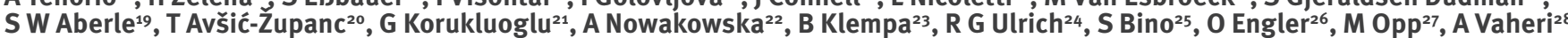

1. Research Laboratory for Vector-borne Diseases and National Reference Laboratory for Hantavirus Infections, Brussels, Belgium

2. Cantacuzino Institute, Vector-Borne Diseases Laboratory, Bucharest, Romania

3. National Center for Infectious and Parasitic Diseases, Sofia, Bulgaria

4. Unit of the Biology of Emerging Viral Infections (UBIVE), Institut Pasteur, Lyon, France

5. Department of Virology, Erasmus University Hospital, Rotterdam, the Netherlands

6. Centre for Vectors and Infectious Diseases Research (CEVDI), National Institute of Applied Sciences (INSA), National Institute of Health Dr. Ricardo Jorge, Águas de Moura, Portugal

7. Swedish Institute for Communicable Disease Control (SMI), Karolinska Institute, Stockholm, Sweden

8. Clinical Centre, University of Sarajevo, Institute of Clinical Microbiology, Sarajevo, Bosnia and Herzegovina

9. Aristotle University of Thessaloniki, School of Medicine, Thessaloniki, Greece

10. Arbovirus and Imported Viral Disease Unit, National Centre for Microbiology, Institute for Health Carlos III, Majadahonda, Spain 11. Institute of Public Health, Ostrava, Czech Republic

12. Department of Virology and Rickettsiology, Bundeswehr Institute for Microbiology, Munich, Germany

13. National Centre for Epidemiology, Budapest, Hungary

14. Department of Virology, National Institute for Health Development, Tallinn, Estonia

15. Department of Medical Microbiology, University College Dublin, Dublin, Ireland

16. Department of Infectious, Parasitic and Immunomediate Diseases, Istituto Superiore di Sanitá, Laboratory of Virology, Rome, Italy 17. Institute of Tropical Medicine, Antwerp, Belgium

18. Norwegian Institute of Public Health, Division of Infectious Disease Control, Oslo, Norway

19. Department of Virology, Medical University of Vienna, Vienna, Austria

20. University of Ljubljana, Medical Faculty, Institute of Microbiology and Immunology, Ljubljana, Slovenia

21. Refik Saydam National Public Health Agency, Sihhiye, Ankara, Turkey

22. Medical Diagnostic Laboratory, Voivodeship Sanitary-Epidemiological Station, Rzeszów, Poland

23. Institute of Virology, Slovak Academy of Sciences, Bratislava, Slovakia

24. Friedrich-Loeffler Institute, Federal Research Institute for Animal Health, World Organisation for Animal Health Collaborating Centre for Zoonoses in Europe, Institute for Novel and Emerging Infectious Diseases, Greifswald - Insel Riems, Germany 25. Institute of Public Health, Control of Infectious Diseases, Tirana, Albania

26. Spiez Laboratory, Biology - Virology Group, Spiez, Switzerland

27. Laboratoire National de Santé, Virologie, Luxembourg

28. Department of Virology, Haartman Institute, University of Helsinki, Helsinki, Finland

Heyman P, Ceianu CS, Christova I, Tordo N, Beersma M, João Alves M, Lundkvist A, Hukic M, Papa A, Tenorio A, Zelená H, Eßbauer S, Visontai I, Golovljova I, Connell J, Nicoletti L, Van Esbroeck M, Gjeruldsen Dudman S, Aberle SW, Avšić-Županc T, Korukluoglu G, Nowakowska A, Klempa B, Ulrich RG, Bino S, Engler O, Opp M, Vaheri A. A five-year perspective on the situation of haemorrhagic fever with renal syndrome and status of the hantavirus reservoirs in Europe, 2005-2010. Euro Surveill. 2011;16(36):pii=19961. Available online: http://www.eurosurveillance.org/ViewArticle.aspx?Articleld=19961

Article published on 8 september 2011

Hantavirus infections are reported from many countries in Europe and with highly variable annual case numbers. In 2010, more than 2,000 human cases were reported in Germany, and numbers above the baseline have also been registered in other European countries. Depending on the virus type human infections are characterised by mild to severe forms of haemorrhagic fever with renal syndrome. The member laboratories of the European Network for diagnostics of Imported Viral Diseases present here an overview of the progression of human cases in the period from 2005 to 2010. Further we provide an update on the available diagnostic methods and endemic regions in their countries, with an emphasis on occurring virus types and reservoirs.

\section{Introduction}

Hantaviruses (family Bunyaviridae, genus Hantavirus) are enveloped RNA viruses that have rodents and insectivores as hosts and are transmitted by aerosols of host excreta or by direct contact to humans. At least five hantaviruses, Puumala (PUUV), Dobrava (DOBV), Saaremaa (SAAV), Tula (TULV) and Seoul virus (SEOV), circulate in Europe. The most prominent and most widely occurring hantavirus in Europe is PUUV, transmitted by the bank vole (Myodes glareolus). PUUV causes a mild form of haemorrhagic fever with renal syndrome (HFRS), called nephropathia epidemica (NE). DOBV is transmitted by the yellow-necked field mouse (Apodemus flavicollis) and is known to cause more severe HFRS [1,2]. SAAV, which is closely related to DOBV, is carried by the striped field mouse ( $A$. agrarius). It should be noted that the hantavirus strains associated with $A$. agrarius in central Europe and Russia have been shown to be phylogenetically distinct from the north-eastern European SAAV strains as well as from strains associated with $A$. flavicollis (DOBV-Af lineage) or the strains associated with the 
TABLE 1

Carrier species, endemic regions and diagnostic tools for hantaviruses, Europe ( $\mathrm{n}=30$ ENIVD member countries)

\begin{tabular}{|c|c|c|c|c|c|c|c|c|}
\hline & \multicolumn{8}{|c|}{ Carrier species for } \\
\hline & Puumala virus & Tula virus & Seoul virus & Dobrava virus & Saaremaa virus & Laihia virus & Asikkala virus & Seewis virus \\
\hline Austria & $\begin{array}{l}\text { Myodes } \\
\text { glareolus }\end{array}$ & $\begin{array}{l}\text { Microtus } \\
\text { arvalis }\end{array}$ & & & & & & \\
\hline Belgium & $\begin{array}{l}\text { Myodes } \\
\text { glareolus }\end{array}$ & $\begin{array}{l}\text { Microtus } \\
\text { arvalis }\end{array}$ & $\begin{array}{l}\text { Rattus } \\
\text { norvegicus }\end{array}$ & & & & & \\
\hline $\begin{array}{l}\text { Bosnia and } \\
\text { Herzegovina }\end{array}$ & $\begin{array}{l}\text { Myodes } \\
\text { glareolus }\end{array}$ & & & $\begin{array}{l}\text { Apodemus } \\
\text { flavicollis }\end{array}$ & & & & \\
\hline Bulgaria & $\begin{array}{l}\text { Myodes } \\
\text { glareolus }\end{array}$ & & & $\begin{array}{l}\text { Apodemus } \\
\text { flavicollis }\end{array}$ & & & & \\
\hline \multicolumn{9}{|l|}{ Cyprus } \\
\hline Czech Republic & $\begin{array}{l}\text { Myodes } \\
\text { glareolus }\end{array}$ & $\begin{array}{l}\text { Microtus } \\
\text { arvalis }\end{array}$ & & $\begin{array}{l}\text { Apodemus } \\
\text { flavicollis }\end{array}$ & & & & \\
\hline Denmark & $\begin{array}{l}\text { Myodes } \\
\text { glareolus }\end{array}$ & & & & & & & \\
\hline Estonia & $\begin{array}{l}\text { Myodes } \\
\text { glareolus }\end{array}$ & & & & $\begin{array}{l}\text { Apodemus } \\
\text { agrarius }\end{array}$ & & & \\
\hline Finland & $\begin{array}{l}\text { Myodes } \\
\text { glareolus }\end{array}$ & $\begin{array}{l}\text { Microtus } \\
\text { arvalis }\end{array}$ & & & $\begin{array}{l}\text { Apodemus } \\
\text { agrarius }\end{array}$ & $\begin{array}{l}\text { Neomys } \\
\text { fodiens }\end{array}$ & Sorex minutus & Sorex araneus \\
\hline France & $\begin{array}{l}\text { Myodes } \\
\text { glareolus }\end{array}$ & $\begin{array}{l}\text { Microtus } \\
\text { arvalis }\end{array}$ & $\begin{array}{l}\text { Rattus } \\
\text { norvegicus }\end{array}$ & & & & & \\
\hline Germany & $\begin{array}{l}\text { Myodes } \\
\text { glareolus }\end{array}$ & $\begin{array}{l}\text { Microtus } \\
\text { arvalis } \\
\text { Microtus } \\
\text { agrestis }\end{array}$ & & $\begin{array}{l}\text { Apodemus } \\
\text { flavicollis }\end{array}$ & $\begin{array}{l}\text { Apodemus } \\
\text { agrarius }\end{array}$ & & & Sorex araneus \\
\hline Greece & & & & $\begin{array}{l}\text { Apodemus } \\
\text { flavicollis }\end{array}$ & & & & \\
\hline Hungary & $\begin{array}{l}\text { Myodes } \\
\text { glareolus }\end{array}$ & $\begin{array}{l}\text { Microtus } \\
\text { arvalis }\end{array}$ & & $\begin{array}{l}\text { Apodemus } \\
\text { flavicollis }\end{array}$ & $\begin{array}{l}\text { Apodemus } \\
\text { agrarius }\end{array}$ & & & \\
\hline \multicolumn{9}{|l|}{ Italy } \\
\hline Ireland & $\begin{array}{l}\text { Myodes } \\
\text { glareolus }\end{array}$ & & $\begin{array}{l}\text { Rattus } \\
\text { norvegicus }\end{array}$ & & & & & \\
\hline Lithuania & $\begin{array}{l}\text { Myodes } \\
\text { glareolus }\end{array}$ & $\begin{array}{l}\text { Microtus } \\
\text { arvalis }\end{array}$ & & $\begin{array}{l}\text { Apodemus } \\
\text { flavicollis }\end{array}$ & $\begin{array}{l}\text { Apodemus } \\
\text { agrarius }\end{array}$ & & & \\
\hline Luxembourg & $\begin{array}{l}\text { Myodes } \\
\text { glareolus }\end{array}$ & & & & & & & \\
\hline the Netherlands & $\begin{array}{l}\text { Myodes } \\
\text { glareolus }\end{array}$ & $\begin{array}{l}\text { Microtus } \\
\text { arvalis }\end{array}$ & & & & & & \\
\hline Norway & $\begin{array}{l}\text { Myodes } \\
\text { glareolus }\end{array}$ & & & & & & & \\
\hline Poland & $\begin{array}{l}\text { Myodes } \\
\text { glareolus }\end{array}$ & & & $\begin{array}{l}\text { Apodemus } \\
\text { flavicollis }\end{array}$ & & & & \\
\hline Portugal & & & $\begin{array}{l}\text { Rattus } \\
\text { norvegicus }\end{array}$ & & & & & \\
\hline Romania & $\begin{array}{l}\text { Myodes } \\
\text { glareolus }\end{array}$ & & & $\begin{array}{l}\text { Apodemus } \\
\text { flavicollis }\end{array}$ & & & & \\
\hline Russia & $\begin{array}{l}\text { Myodes } \\
\text { glareolus }\end{array}$ & $\begin{array}{l}\text { Microtus } \\
\text { arvalis }\end{array}$ & $\begin{array}{l}\text { Rattus } \\
\text { norvegicus }\end{array}$ & $\begin{array}{l}\text { Apodemus } \\
\text { flavicollis }\end{array}$ & $\begin{array}{l}\text { Apodemus } \\
\text { agrarius }\end{array}$ & & & \\
\hline Slovakia & $\begin{array}{l}\text { Myodes } \\
\text { glareolus }\end{array}$ & & & $\begin{array}{l}\text { Apodemus } \\
\text { flavicollis }\end{array}$ & $\begin{array}{l}\text { Apodemus } \\
\text { agrarius }\end{array}$ & & & \\
\hline Slovenia & $\begin{array}{l}\text { Myodes } \\
\text { glareolus }\end{array}$ & $\begin{array}{l}\text { Microtus } \\
\text { arvalis, } \\
\text { Microtus } \\
\text { agrestis, } \\
\text { Microtus } \\
\text { subterraneus }\end{array}$ & & $\begin{array}{l}\text { Apodemus } \\
\text { flavicollis }\end{array}$ & $\begin{array}{l}\text { Apodemus } \\
\text { agrarius }\end{array}$ & & & \\
\hline \multicolumn{9}{|l|}{ Spain } \\
\hline Sweden & $\begin{array}{l}\text { Myodes } \\
\text { glareolus }\end{array}$ & & & & & & & \\
\hline \multicolumn{9}{|l|}{ Switzerland } \\
\hline Turkey & $\begin{array}{l}\text { Myodes } \\
\text { glareolus }\end{array}$ & & & $\begin{array}{l}\text { Apodemus } \\
\text { flavicollis }\end{array}$ & & & & \\
\hline United Kingdom & & & & & & & & \\
\hline
\end{tabular}

ELISA: enzyme-linked immunosorbent assay; ENIVD: European Network for diagnostics of Imported Viral Diseases; IFA: immunofluorescence assay; RT-PCR: reverse transcription polymerase chain reaction.

Fields with symbols indicate that the method is in use (x) or not in use (-).

The question marks refer to the presence of an unidentified hantavirus. In Portugal, the Algerian mouse (Mus spretus), the house mouse (Mus musculus) and the wood mouse (Apodemus sylvaticus), species that are so far not known to harbour a hantavirus, were found positive for hantaviral antibodies. No identification of the infecting hantavirus serotype has been achieved until now.

Data as reported by ENIVD members. This list compiles only the obtained information by means of the 2010 questionnaire and not the current state of the literature. 
Yes $\quad 95 \%$ in the south-east (Styria, Carinthia,

Burgenland) $5 \%$ in the north-west (Upper Austria)

No Nationwide; $85 \%$ in the south, $15 \%$ in the north

\begin{tabular}{l|l} 
Yes \\
$(n=1)$
\end{tabular}$\quad$ Central and north-east

No South and south-west

No

No

DOBV (northern Moravia) PUUV (southern Bohemia)

No

\begin{tabular}{l|l} 
No & North, east and couth-east
\end{tabular}

\begin{tabular}{l|l}
$<0,1 \%$ & Nationwide except northern Lapland
\end{tabular}

\begin{tabular}{l|l} 
No & North-east, Jura
\end{tabular}

No $\quad$ DOBV: north-east

PUUV: almost nationwide with hotspots in North Rhine-Westphalia, Lower Saxony, Bavaria and Baden-Württemberg

\begin{tabular}{l|l} 
No & North and north-west
\end{tabular}

\section{Yes}

Nationwide

No $\quad$ None

No

\begin{tabular}{|l|l|} 
& \\
\hline & \\
\hline & \\
\hline Mus musculus & Mus spretus \\
\hline
\end{tabular}

Mus spretus
( $n=1$ probable) Vrancea counties

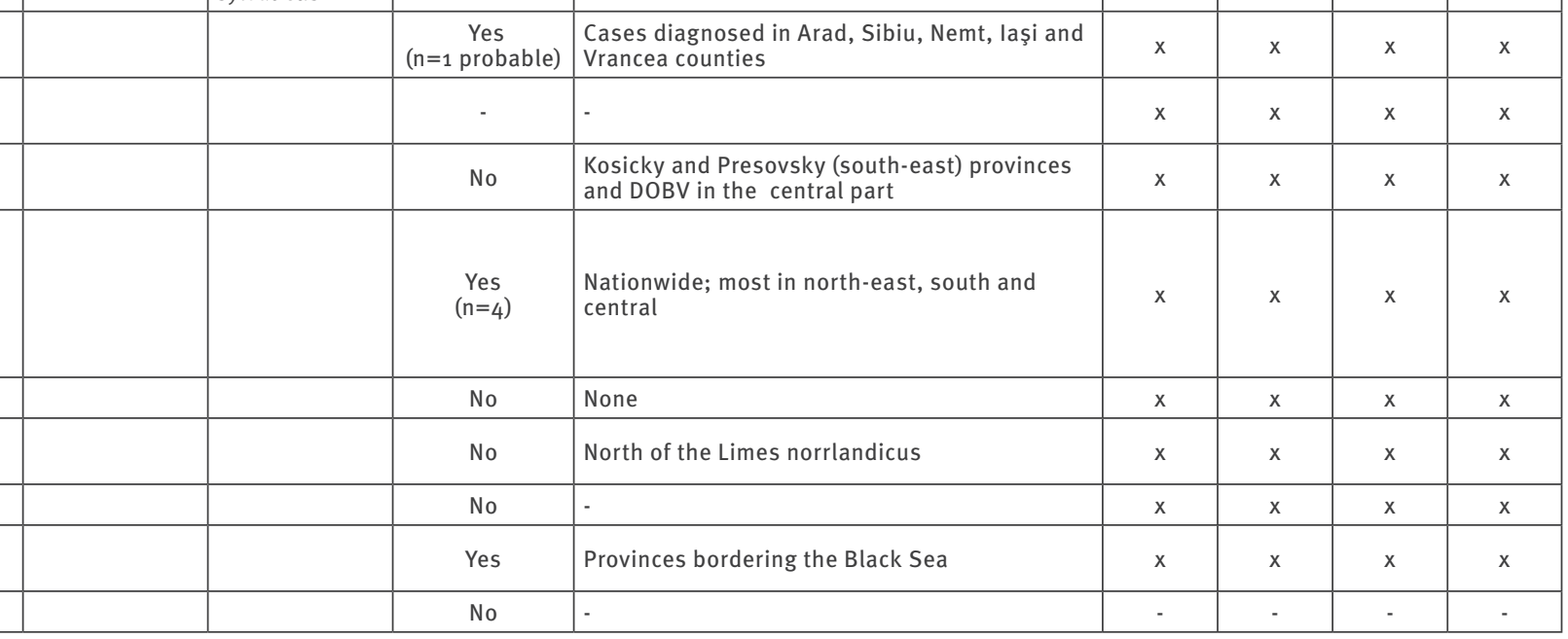


Black Sea field mouse (A. ponticus) (DOBV-Ap lineage). It is from an epidemiological point of view currently impossible to distinguish between the lineages by routine diagnostics when the viral RNA sequence is not available $[3,4]$. TULV is transmitted by the common vole (Microtus arvalis), the field vole (M. agrestis) and the southern vole $(M$. levis, also known as $M$. rossiaemeridionalis). This virus has not definitely been linked to human disease. SEOV, transmitted by the brown and black rat (Rattus norvegicus and $R$. rattus), causes mild HFRS in Asia and in many harbour cities worldwide. In Europe, it has so far only been identified once as a human pathogen, in an unpublished case in France that was confirmed by focus reduction neutralisation test [1]. During the past decade several hantaviruses have been discovered that have insectivores as carriers. In Europe these are Laihia, Asikkala and Seewis virus, transmitted, respectively, by the Eurasian water shrew (Neomys fodiens), the Eurasian pygmy shrew (Sorex minutus) and the common shrew (Sorex araneus) (Table 1).

In the past decade (2000-2009) oscillations in the number of hantavirus infections have been reported [5]. The unusually high number of hantavirus infections in Germany in 2010, with 327 cases between January and April in Baden-Württemberg [6], prompted the European Centre for Disease Prevention and Control $(E C D C)$ to request an update on the hantavirus situation in Europe from the European Network for diagnostics of Imported Viral Diseases (ENIVD) and its Collaborative Laboratory Response Network (CLRN). The present article summarises the current knowledge on the occurrence of hantaviruses based on a survey in 30 European countries.

TABLE 2

Human cases of hantavirus infection in Europe, 2005-2010 ( $\mathrm{n}=30$ ENIVD countries)

\begin{tabular}{|c|c|c|c|c|c|c|c|}
\hline & $2005^{a}$ & 2006 & 2007 & 2008 & 2009 & $2010^{c}$ & Total $^{\mathrm{d}}$ \\
\hline Austria & 16 & 12 & 78 & 33 & 29 & 13 & 351 \\
\hline Belgium & 372 & 163 & 298 & 336 & 182 & 161 & 2,845 \\
\hline Bosnia and Herzegovina & 21 & 26 & 8 & 25 & 19 & 8 & 732 \\
\hline Bulgaria & 5 & 0 & 2 & 4 & 5 & 2 & 56 \\
\hline Cyprus & 0 & 0 & NA & NA & NA & NA & $\mathbf{0}$ \\
\hline Czech Republic & 3 & 2 & 4 & 5 & 7 & 4 & 43 \\
\hline Denmark & 0 & 0 & NA & NA & NA & 0 & o \\
\hline Estonia & NA & $\mathrm{e}$ & 7 & 11 & 17 & 4 & 39 \\
\hline Finland & 2,526 & 1,863 & 1,743 & 3,259 & 1,919 & 326 & 31,919 \\
\hline France & 253 & 24 & 127 & 84 & 62 & 100 & 1,913 \\
\hline Germany & 447 & 72 & 1,688 & 243 & 181 & 1,527 & 4,956 \\
\hline Greece & 5 & 4 & 5 & 1 & 4 & 3 & 52 \\
\hline Hungary & 6 & NA & 16 & 6 & 11 & 7 & 342 \\
\hline Italy & 0 & 0 & 0 & 0 & 0 & 0 & o \\
\hline Ireland & NA & 0 & 0 & 0 & 0 & 0 & 0 \\
\hline Lithuania & NA & 0 & $\mathrm{NA}$ & NA & NA & NA & 9 \\
\hline Luxembourg & 17 & 11 & 10 & 7 & 3 & 10 & 60 \\
\hline The Netherlands & 3 & 3 & 32 & 32 & 12 & 14 & 133 \\
\hline Norway & 64 & 22 & 76 & 50 & 21 & 8 & 1234 \\
\hline Poland & NA & NA & 17 & 3 & 6 & 5 & 31 \\
\hline Portugal & 1 & 4 & 2 & 4 & 0 & NA & 37 \\
\hline Romania & 1 & 1 & 2 & 4 & 9 & 4 & 21 \\
\hline Russia & 7,256 & 7,157 & NA & NA & NA & NA & 173,652 \\
\hline Slovakia & & & 22 & 3 & 11 & 6 & 42 \\
\hline Slovenia & 24 & 5 & 14 & 46 & 5 & 8 & 294 \\
\hline Spain & 0 & 0 & 0 & $1^{\mathrm{b}}$ & 0 & 0 & 1 \\
\hline Sweden & 330 & 213 & 2,195 & 569 & 53 & 138 & 7,198 \\
\hline Switzerland & 0 & 0 & 1 & 0 & 0 & 0 & 2 \\
\hline Turkey & NA & NA & NA & NA & 23 & NA & 23 \\
\hline United Kingdom & & & & & & & 6 \\
\hline
\end{tabular}

ENIVD: European Network for diagnostics of Imported Viral Diseases; NA: data not made available.

${ }^{a}$ Previous years: see [7].

${ }^{b}$ Imported case.

' Up to 31 August 2010.

${ }^{d}$ Total of diagnosed hantavirus cases since start of surveillance in the specified country. 
In general HFRS is characterised by high fever for up to four days and unspecific symptoms at the onset of the disease such as headache, thrombocytopenia and influenza-like symptoms, followed by nausea, abdominal pain and vomiting. After four to 10 days renal manifestations characterised by oliguria and transient renal failure and later polyuria may occur $[1,2]$.

\section{Methods}

The ENIVD hantavirus working group sent a questionnaire to all ENIVD members $(\mathrm{N}=30$, see Table 1) requesting information on the occurrence of clinically apparent cases of hantavirus infection according to the ENIVD case definition during the period from January 2006 to end of August 2010, fatalities due to hantavirus infection, the hantavirus carrier species present in the country and available diagnostic methods. The questionnaire was similar to the one used in 2006 [7], and was intended to update the information already available up to 2006. In addition, the average numbers of clinically apparent cases reported annually by ENIVD collaborating countries were calculated for the two decades 1990-1999 and 2000-2009 and were used to assess the reported country case numbers in the individual years. A year was regarded as a normal year when the number of cases matched the average case numbers, plus or minus $10 \%$ recorded for the respective country during the decade ending in the respective year. Case numbers $10-50 \%$ higher than the 10 -year average were considered moderate activity, numbers 50-100\% higher were considered slightly elevated and numbers at least $100 \%$ higher than the average number were considered increased activity.

\section{Results}

The annual number of cases diagnosed per country in the years 2006 to 2009 and 2010 up to end of August is summarised in Table 2. The year 2005 is added in order to facilitate the transition between this report and the previous one published in 2008 [7]. 2005 was a year with increased hantavirus activity, with approximately twice as many cases as in the ten previous years in Belgium, Finland, France, Luxembourg, Norway and some regions in Germany, especially North Rhine Westphalia, Lower Saxony and BadenWürttemberg [8]. In the year 2007 Belgium and Norway reported more human infections than the annual average of clinically apparent infections calculated for the decade 2000-2009. In the same year, France, Austria, Germany and Hungary reported between three- and

\section{FIGURE 1}

Countries with increased (over the previous year) hantavirus activity, Europe, 2005-2010 ( $\mathrm{n}=30$ ENIVD countries)
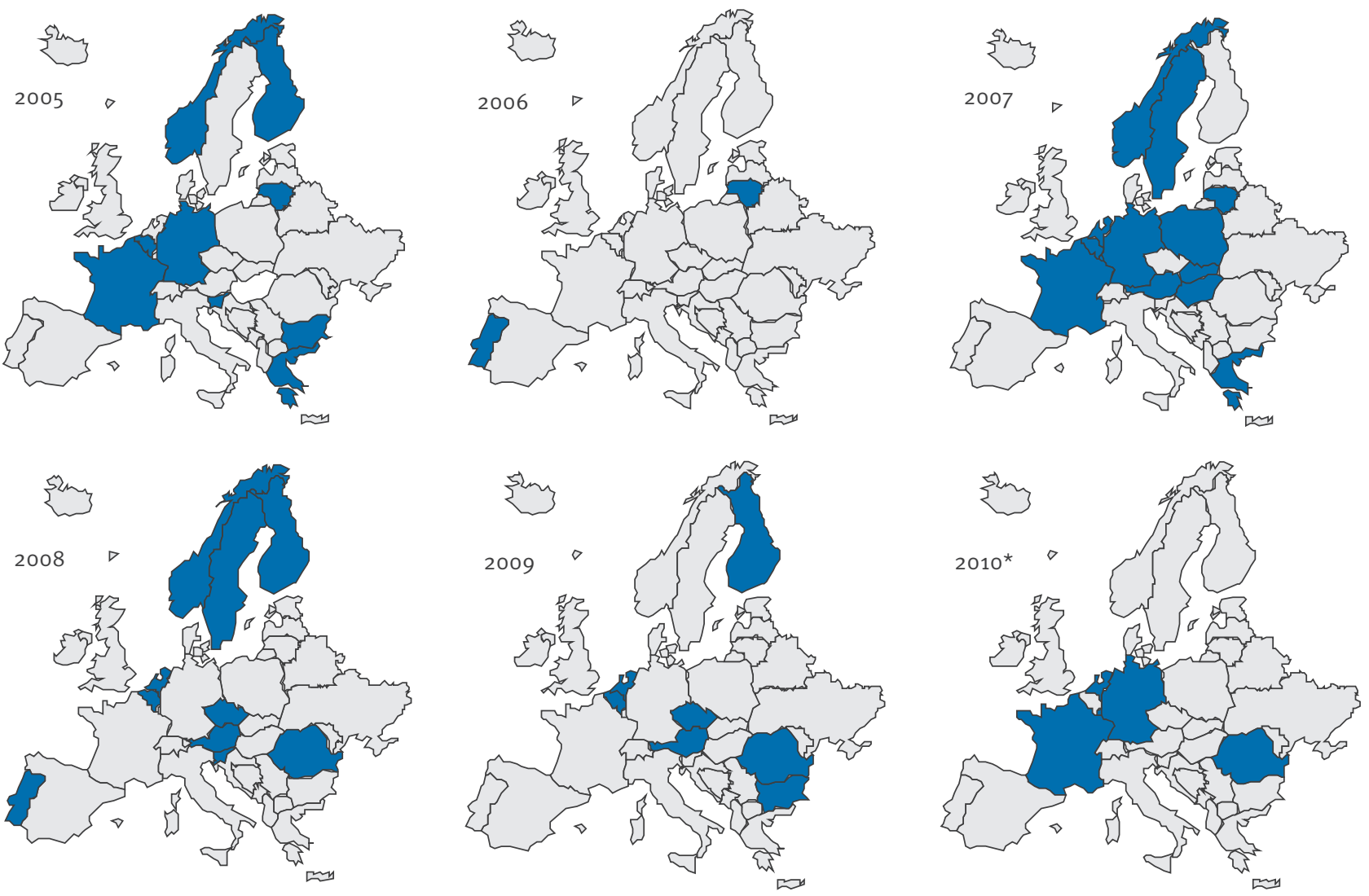

$\square$ Increased hantavirus activity

ENIVD: European Network for diagnostics of Imported Viral Diseases.

* The epidemic situation for 2010 is depicted up until the 31 August 2010. 
five-fold elevated case numbers, and Sweden 10-fold elevated numbers compared with the annual average of the decade. These were the highest numbers of hantavirus infections ever seen in Germany and Sweden. The year 2008 was again an epidemic year in Belgium, with 336 reported cases, and also in Finland, where a record number of 3,259 cases were observed. All other European countries that had data available (Table 2) noted normal hantavirus activity in 2008. In 2009, all European countries had case numbers that corresponded to the annual average of the past decade. In 2010 it became clear already in February that the hantavirus activity in Germany was high, which was confirmed by the number of diagnosed cases up to August 2010 that reached 2.017 [9]. In bordering countries, i.e. Belgium, France, Luxembourg and The Netherlands, the hantavirus activity was normal or moderately elevated in comparison to the annual average of the past decade. In Austria, the Czech Republic, Denmark, Poland and Switzerland the hantavirus activity in 2010 remained low (Table 2 and Figure 1).

From the available information it was possible to calculate the yearly average number of diagnosed cases in Europe. For the 10-year period 1990 to 1999 this annual average was 1,671 cases, calculated for those countries from which reliable data on human infections were available, i.e. Belgium, Finland, France, Hungary, the Netherlands, Norway, Portugal, Slovenia and Sweden, as well as those countries from which apparently not all cases had been reported, i.e. Austria, BosniaHerzegovina, the Czech Republic and Greece. However, for the period 2000 to 2009 the annual average was significantly higher, namely 3,138 cases, including available data for further countries. It is at present impossible to state whether there is a real increase in hantavirus cases in Europe or whether the observation is influenced by increased awareness and better use of diagnostic tools. It is noteworthy that in the period 1990 to 1999, the years 1995, 1998 and 1999 were above the calculated arithmetic mean of 1.671 cases (Figure 2), and in the period between 2000 and 2010

\section{FIGURE 2}

Annual number of human cases of hantavirus infection in Europe, 1990-1999 (n=29 ENIVD countries, excluding Russia)

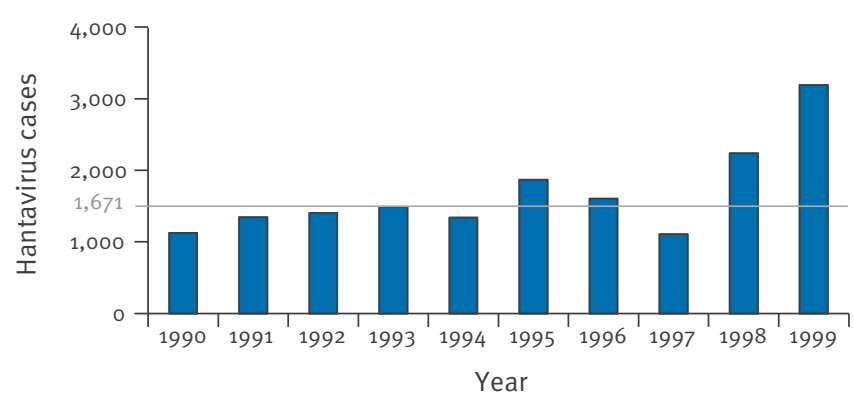

ENIVD: European Network for diagnostics of Imported Viral Diseases. Grey line: Average number of diagnosed cases per year: 1,671. the years 2002, 2005, 2007, 2008 and 2010 showed more than average activity, i.e. above the arithmetic mean of 3,138 cases (Figure 3 ). This is in accordance with already recognised epidemic years in different European countries (Table 2).

Further information we obtained on the carrier species present in the participating countries and the viruses detected in those rodents is summarised in Table 1. It confirmed earlier observations regarding the prominent role of PUUV and DOBV in Europe. Hantaviruses transmitted by insectivores were only found in Finland and Austria in this survey (see Table 1). No link to human disease has been shown so far for these viruses. Given the established role of the rodent-borne viruses PUUV, DOBV and possibly SAAV as human HFRS pathogens in Europe, it seems unlikely that insectivore-borne hantaviruses play a major role as pathogens.

Fatal cases due to hantavirus infection are rare in Europe and mostly linked to DOBV infection. Although some fatal cases have been linked to PUUV infection, the mortality rate due to this virus remains lower than $0.1 \%$.

\section{Discussion}

Data on human hantavirus infections have been registered in 30 European countries since 2005. Our knowledge of the disease, virus geno- and serotypes, hosts and diagnostic capacities has increased over the past decade. However, there seem to be large regional differences in the case numbers. The update on endemic regions in the participating countries confirmed the focal aspect of hantavirus infections (see Table 1). In the majority of countries, the endemic regions are forested areas that provide sufficient shelter and food for rodent populations.

\section{FIGURE 3}

Annual number of human cases of hantavirus infection in Europe, 2000-2009 ( $n=29$ ENIVD countries, excluding Russia)

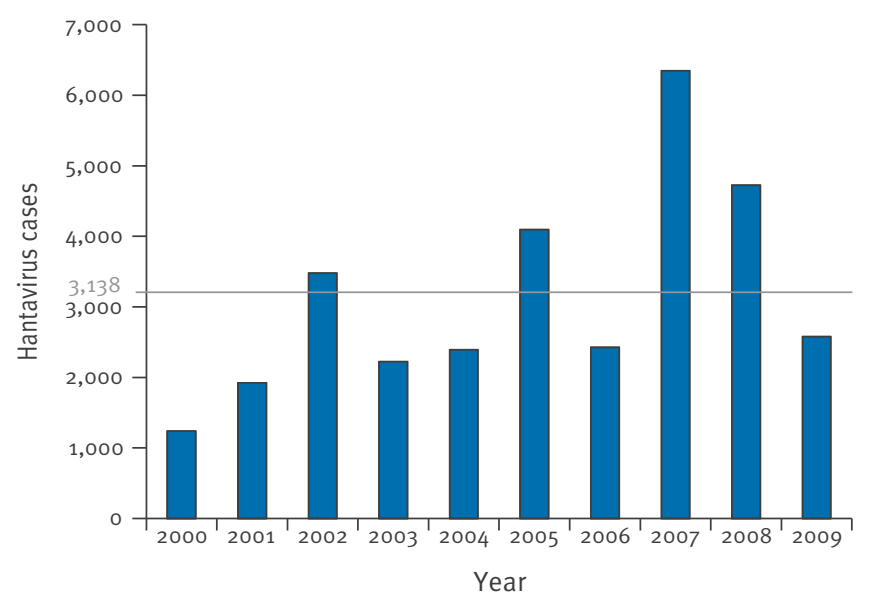

ENIVD: European Network for diagnostics of Imported Viral Diseases. Grey line: Average number of diagnosed cases per year: 3,138. 
Epidemic peaks may be linked to times of favourable climatic conditions when an abundance of available food triggers a peak in the rodent population $[8,10]$. A relation between climate, high density of the rodent population and increased virus prevalence in rodent populations was also observed [4]. This puts humans at increased risk of contact with infected rodents and their excreta. According to preliminary findings, it was such a scenario that led to the spectacular increase in cases in Germany in 2010 [6]. Although mast events (increased seed production of various trees) seem to be of importance in triggering hantavirus epidemics, it should be remembered that only hantavirus epidemics in Atlantic and continental western Europe are mast-driven (although this seems not entirely true for Germany as in some years the country experienced very regional outbreaks), while other mechanisms drive these events in northern and eastern Europe $[1,2]$.

The bank vole ( $M$. glareolus), the principle vertebrate host for PUUV, is a generalist polyphagous species, i.e. eating seeds and fruits and occasionally invertebrates. It only acquires $50 \%$ of its energy intake from hard fruits and this only in the winter months. The yellownecked field mouse ( $A$. flavicollis), the principle vertebrate host for DOBV, is predominantly a seed eater, but the invertebrate portion of its diet can be considerably higher than for the bank vole. The diet of both M. glareolus and $A$. flavicollis varies considerably in different regions in Europe: in Atlantic western Europe (Belgium, France) oak and beech seed crops are instrumental $[10,11]$, while in continental Europe (the Białowieża Primeval forest in Poland, for instance) oak (Quercus petraea) and hornbeam (Carpinus betulus) seed crops regulate population sizes of both species $[12,13]$. Both the bank vole and the yellow-necked field mouse prefer a forest environment. The third rodent species of interest, the striped field mouse ( $A$. agrarius, carrier of SAAV), is typical of a mixed habitat of agricultural fields and forest, and its population dynamics thus relate not only to forest conditions but also to anthropogenic factors [14].

For all three species, winter survival is related to food availability in the preceding summer and autumn, spring numbers are dependent on winter mortality, which according to the rodent catchers is estimated to reach on average $70 \%$ of autumn numbers for voles and $85 \%$ for mice, and summer/autumn numbers are primarily related to vegetation biomass and temperature.

The hantavirus activity peaks indicated by our data did not in all years correlate with mast cycles. Although mast events are supposed to occur over large areas and even on sub-continental level, hantavirus epidemics in western Europe can probably not be related solely to mast events of one tree species, given the highly different levels of hantavirus activity in neighbouring countries in 2005, 2007, 2008 and 2010 (see Table 2) where mast events occur simultaneously. Unfortunately, detailed information about seed crops of the different endemic tree species, e.g. beech (Fagus sylvatica), oak (Quercus sp.) and hornbeam (C. betulus), that can significantly influence rodent winter survival rates are not always available in most countries.

At present, all European countries dispose of the same range of diagnostic tools (for a recent review, see [15]), i.e. IgG and IgM IFA and ELISA, classical or real-time RT-PCR methods targeting specific hantaviral sero-/ genotypes followed by sequence analysis of the amplicons in order to study the molecular epidemiology of the circulating strains. Neutralisation tests are, due to the special requirements of these tests, only available in a few countries and are in general only used for research purposes.

\section{Conclusions}

Hantavirus infections continue to be a risk in the European Union. To our knowledge, notification systems have not changed in the past decade. In the past 10 years the annual number of diagnosed cases has significantly increased but it remains unclear whether this is due to higher awareness and better diagnostic tools or to a real increase in acquired infections. Epidemics occur locally and in foci, i.e. in regions where climatic, biotic and abiotic conditions pave the way for the carrier species to become abundant and humans to come in contact with the virus.

Infections caused by PUUV remain the most prevalent in Europe, and in regions where the virus is circulating, the number of infected individuals can reach hundreds or thousands per year, DOBV infections on the other hand are much less frequent, and important outbreaks are scarce. Incidence data on hantavirus infections are unfortunately not available.

The 2010 PUUV outbreak in Germany seems to be an isolated incident and is currently closely monitored by the local authorities. Further longitudinal studies are needed in Europe to better understand the factors that drive the oscillation of human cases on a local, regional and continental scale including a combination of landscape and land use, habitat, climate and geographical parameters.

\section{Acknowledgments}

All authors have contributed equally to the data collection for this article. The authors would like to thank all their collaborators in the different countries that participated in the creation of the country report files, including local and governmental health authorities. The authors also thank the ECDC for its continued support and its guidance of the ENIVD-CLRN network.

\section{References}

1. Heyman P, Vaheri A, Lundkvist A, Avsic-Zupanc T. Hantavirus infections in Europe: from virus carriers to a major publichealth problem. Expert Rev Anti Infect Ther. 2009;7(2):205-17.

2. Vaheri A, Mills JN, Spiropoulou CF, Hjelle B. Hantaviruses. In: Palmer SR, Lord Soulsby, Torgerson PR, Brown DWG, editors. 
Oxford Textbook of Zoonoses - Biology, Clinical Practice and Public Health Control. 2nd ed: Oxford University Press; 2011. p. 307-22.

3. Klempa B, Stanko M, Labuda M, Ulrich R, Meisel H, Krüger DH. Central European Dobrava hantavirus isolate from striped field mouse, Apodemus agrarius. J Clin Microbiol. 2005;43(6):2756-63.

4. Klempa B, Tkachenko EA, Dzagurova TK, Yunicheva YV, Morozov VG, Okulova NM, et al. Hemorrhagic fever with renal syndrome caused by 2 lineages of Dobrava hantavirus, Russia. Emerg Infect Dis. 2008;14(4):617-25.

5. Mailles A, Abu Sin M, Ducoffre G, Heyman P, Koch J, Zeller $\mathrm{H}$, et al. Larger than usual increase in cases of hantavirus infections in Belgium, France and Germany, June 2005. Euro Surveill. 2005;10(29):pii=2754. Available from: http://www. eurosurveillance.org/ViewArticle.aspx?Articleld=2754

6. Faber MS, Ulrich RG, Frank C, Brockmann SO, Pfaff GM, Jacob J, et al. Steep rise in notified hantavirus infections in Germany, April 2010. Euro Surveill. 2010;15(20):pii=19574. Available from: http://www.eurosurveillance.org/ViewArticle. aspx?Articleld $=19574$.

7. Heyman P, Vaheri A, the ENIVD members. Situation of hantavirus infections and haemorrhagic fever with renal syndrome in European countries as of December 2006. Euro Surveill. 2008;13(28): pii=18925. Available from: http://www. eurosurveillance.org/ViewArticle.aspx?Articleld=18925

8. Essbauer SS, Schmidt-Chanasit J, Madeja EL, Wegener W, Friedrich R, Petraityte R, et al. Nephropathia epidemica outbreak in a metropolitan area, Germany. Emerg Infect Dis. 2007;13(8):1271-3.

9. SurvStat@RKI. Berlin: Robert Koch Institute. [Accessed 25 May 2011). Available from: http://www3.rki.de/Survstat/ QueryForm.aspx

10. Tersago K, Verhagen R, Servais A, Heyman P, Ducoffre G, Leirs $H$. Hantavirus disease (nephropathia epidemica) in Belgium: effects of tree seed production and climate. Epidemiol Infect. 2009;137(2):250-6.

11. Tersago K, Verhagen R, Vapalahti O, Heyman P, Ducoffre G, Leirs H. Hantavirus outbreak in Western Europe: reservoir host infection dynamics related to human disease patterns. Epidemiol Infect. 2011;139(3):381-90.

12. Stenseth NC, Viljugren $\mathrm{H}$, Jedrzejewski W, Mysterus $A$, Pucek Z. Population dynamics of Clethrionomys glareolus and Apodemus flavicollis: seasonal components of density dependence and density independence. Acta Theriol. 2002;47 (Suppl. 1):39-67.

13. Pucek Z, Jedrzejewski W, Jedrzejewska B, Pucek M. Rodent population dynamics in primeval deciduous forest (Bialowieza National Park) in relation to weather, seed crop and predation. Acta Theriol. 1993;38(2):199-232.

14. Chassovnikarova T, Dimitrov H, Markov G, Mitev D. Distribution and habitat association of field mouse (Apodemus agrarius, Pallas, 1771) in national park "Strandja". Proceedings of the Balkan Scientific Conference of Biology, Plovdiv, 19-21 May 2005. p. 428-36.

15. Vaheri A, Vapalahti O, Plyusnin A. How to diagnose hantavirus infections and detect them in rodents and insectivores. Rev Med Virol. 2008;18(4):277-88. 